\title{
INFLUENCE OF PUBLIC POLICY, PARTICIPATION OF COMMUNITY \\ AND EDUCATION LEVEL TO PUBLIC WELFARE IN PADANG \\ PARIAMAN DISTRICT
}

\author{
Rizki Afri Mulia \\ Lecturer in the State Administration Study Program \\ Imam Bonjol Padang College of Social and Political Sciences \\ Email : rizkiafri_mulia@yahoo.com
}

Development must cover all areas as a whole. Partial development will be difficult to solve problems that arise can even exacerbate existing problems and create new problems. Development that focuses only on one aspect will lead to development failure. This research aims to know: 1) Influence of public policy toward society prosperity in Regency of Padang Pariaman, 2) Influence of Public Participation to society prosperity in Regency of Padang Pariaman, 3) Influence of education level to society prosperity in Padang Pariaman Regency.

The data were collected by survey method with questionnaire. Data analysis technique used in this research is descriptive and quantitative analysis. The data collected are primary and secondary data that can be classified as independent variable and dependent variable. Public policy, public participation, and educational level (independent variables), and the welfare of society in Padang Pariaman (variable affected). Hypothesis testing in this study using multiple linear regression test.

Based on the results of the research note that: 1) Public policy significantly influence the prosperity of the people of Padang Pariaman Regency. This means that the better public policy the better the welfare of the community that is produced 2) The community participation significantly influence the welfare of the people of Padang Pariaman Regency. That is, the increasing number of community participation in the implementation and supervision of the resulting community welfare will be better also 3) The level of education significantly affects the welfare of the people of Padang Pariaman Regency. That is, the higher education in a region or community will be the higher the welfare of the community in the area.

Keywords: Public Policy, Community Participation, Education Level, and People's Welfare 


\title{
ABSTRAK \\ PENGARUH KEBIJAKAN PUBLIK, PARTISIPASI MASYARAKAT DAN \\ TINGKAT PENDIDIKAN TERHADAP KESEJAHTERAAN MASYARAKAT KABUPATEN PADANG PARIAMAN
}

\author{
Rizki Afri Mulia \\ Dosen Program Studi Administrasi Negara \\ Sekolah Tinggi Ilmu Sosial dan Politik Imam Bonjol Padang
}

Email : rizkiafri_mulia@yahoo.com

\begin{abstract}
Pembangunan harus meliputi segala bidang secara menyeluruh. Pembangunan yang dilakukan secara parsial akan sulit menyelesaikan permasalahan yang muncul bahkan dapat memperburuk permasalahan yang sudah ada serta memunculkan permasalahan baru. Pembangunan yang hanya menitikberatkan pada satu aspek akan memicu terjadinya kegagalan pembangunan. Penelitian ini bertujuan untuk mengetahui : 1) Pengaruh kebijakan publik terhadap kesejahteraan masyarakat di Kabupaten Padang Pariaman, 2) Pengaruh Partisipasi Masyarakat terhadap kesejahteraan masyarakat di Kabupaten Padang Pariaman, 3) Pengaruh tingkat pendidikan terhadap kesejahteraan masyarakat di Kabupaten Padang Pariaman

Pengumpulan data dilakukan dengan metode survei dengan kuesioner. Teknik analisa data yang digunakan dalam penelitian ini adalah analisis deskriptif dan kuantitatif. Data yang dikumpulkan merupakan data primer dan sekunder yang dapat digolongkan sebagai variabel bebas dan variabel terikat. Kebijakan publik, partisipasi masyarakat, dan tingkat pendidikan (variabel pengaruh), dan Kesejahteraan masyarakat di Kabupaten Padang Pariaman (variabel terpengaruh). Pengujian hipotesis dalam penelitian ini menggunakan uji regresi linier berganda.

Berdasarkan hasil penelitian diketahui bahwa : 1) Kebijakan publik berpengaruh secara signifikan terhadap kesejahteraan masyarakat Kabupaten Padang Pariaman. Artinya bahwa semakin baik kebijakan publik maka semakin baik pula kesejahteraan masyarakat yang dihasilkan 2) Partisipasi masyarakat berpengaruh secara signifikan terhadap kesejateraan masyarakat Kabupaten Padang Pariaman. Artinya, semakin banyaknya partsipasi masyarakat baik dalam pelaksanaan dan pengawasan maka kesejateraan masyarakat yang dihasilkan akan semakin baik pula 3) Tingkat pendidikan berpengaruh secara signifikan terhadap kesejahteraan masyarakat Kabupaten Padang Pariaman. Artinya, semakin tinggi pendidikan disuatu daerah atau masyarakat maka akan semakin tinggi pula kesejahteraan masyarakat didaerah tersebut.
\end{abstract}

Kata kunci : Kebijakan Publik, Partisipasi Masyarakat, Tingkat Pendidikan, dan Kesejahteraan Masyarakat

\section{A. PENDAHULUAN}


Dalam aspek sosial, bukan saja aspirasi masyarakat ikut dipertimbangkan tetapi juga keberadaan lembaga-lembaga sosial (social capital) juga ikut dipelihara bahkan fungsinya ditingkatkan. Sementara dalam aspek lingkungan, aspek fungsi kelestarian natural capital juga sangat diperhatikan demi kepentingan umat manusia. Dari semua itu, yang terpenting pengambilan keputusan dapat berperilaku dengan baik tanpa kepentingan tertentu dan untuk keuntungan semata (rent seeking). Dengan demikian, hasil-hasil pembangunan dapat dinikmati oleh seluruh masyarakat secara adil melintasi (menembus) batas ruang (inter-region) dan waktu (inter-generation) (Todaro, 2006).

Kualitas hidup masyarakat di suatu negara/daerah tercermin pada Indeks Pembangunan Manusia (IPM) yang mengalami peningkatan setiap tahunnya. Gambar 1 menunjukkan IPM Kabupaten Padang Pariaman pada tahun 2016 tercatat sebesar 66,03 mengalami peningkatan dibandingkan tahun-tahun sebelumnya. Pembangunan ekonomi diantaranya bertujuan mengejar akselerasi pertumbuhan ekonomi, penanganan ketimpangan pendapatan, serta berujung pada pengentasan kemiskinan demi tercapainya kesejahteraan masyarakat. Kabupaten Padang Pariaman terus mengalami penurunan setiap tahunnya, yaitu pada tahun 2006 sebanyak 12\% jiwa sedangkan pada tahun 2013 sebanyak $7,9 \%$ jiwa. Besar kecilnya penduduk miskin sangat dipengaruhi oleh garis kemiskinan, karena penduduk miskin adalah penduduk yang memiliki rata-rata pengeluaran per kapita per bulan dibawah garis kemiskinan. Hal ini di karenakan UMK pada Kabupaten Padang Pariaman mengalami peningkatan.

Berbagai indikator dapat digunakan untuk memantau kemajuan pembangunan di suatu daerah, baik indikator ekonomi maupun indikator sosial. Dalam konteks masyarakat sebagai obyek sosial, maka diperlukan suatu indikator untuk mengukur perkembangan kehidupan/tingkat kesejahteraan masyarakat itu sendiri. Untuk melihat tingkat kesejahteraan dari segi sosisal secara umum, indikator yang digunakan adalah kebijakan pemerintah. Membicarakan Kebijakan Pemerintah tentu tidak terlepas dari apa sebenarnya peran pemerintah yang diamanatkan negara untuk rakyatnya. Pemerintah adalah instrumen negara yang ditugaskan untuk melaksanakan Pemerintahan sesuai dengan Konstitusi Negara. Maka itu "pemerintah" disebut juga sebagai Penyelenggara negara dan harus mengawal dan melaksanakan idiologi negara. Idiologi negara Indonesia adalah tentu mewujudkan Negara Kesejahteraan (Welfare State) sebagaimana tercantum dalam Pembukaan UUD 1945 khususnya yang menyangkut masalah tujuan negara Indonesia, pada intinya dapat dirumuskan sebagai "memajukan kesejahteraan umum dan mencerdaskan kehidupan bangsa yang didasarkan pada prinsip keadilan sosial bagi seluruh rakyat Indonesia". Tujuan yang dimuat di dalam pembukaan tersebut kemudian di dalam batang tubuh UUD 1945 dituangkan dalam berbagai ketentuan yang menyangkut kesejahteraan rakyat.

Menurut Undang-undang No 11 Tahun 2009, Kesejahteraan Sosial adalah kondisi terpenuhinya kebutuhan material, spiritual, dan sosial warga negara agar dapat hidup layak dan mampu mengembangkan diri, sehingga dapat melaksanakan fungsi sosialnya. Permasalahan kesejahteraan sosial yang berkembang dewasa ini menunjukkan bahwa ada warga negara yang belum 
terpenuhi hak atas kebutuhan dasarnya secara layak karena belum memperoleh pelayanan sosial dari negara. Akibatnya, masih ada warga negara yang mengalami hambatan pelaksanaan fungsi sosial sehingga tidak dapat menjalani kehidupan secara layak dan bermartabat. Konsep kesejahteraan menurut (Nasikun, 1996) dapat dirumuskan sebagai padanan makna dari konsep martabat manusia yang dapat dilihat dari empat indikator yaitu : (1) rasa aman (security), (2) Kesejahteraan (welfare), (3) Kebebasan (freedom), dan (4) jati diri (Identity).

Menurut Drewnoski (1974) dalam (Bintarto, 1989), melihat konsep kesejahteraan dari tiga aspek; (1) dengan melihat pada tingkat perkembangan fisik (somatic status), seperti nutrisi, kesehatan, harapan hidup, dan sebagianya; (2) dengan melihat pada tingkat mentalnya, (mental/educational status) seperti pendidikan, pekerjaan, dan sebagainya; (3) dengan melihat pada integrasi dan kedudukan social (social status).

Pembangunan yang efektif membutuhkan keterlibatan (partisipasi) awal dan nyata pada pihak seluruh pemangku kepentingan (stakeholders) dalam penyusunan rancangan kegiatan yang akan mempengaruhi mereka. Sewaktu masyarakat yang terlibat merasa bahwa partisipasi mereka penting, mutu, efektifitas dan efisiensi pembangunan akan meningkat. Pendidikan merupakan salah satu kebutuhan pokok manusia yang harus dipenuhi, yang mempunyai tujuan lebih tinggi dari sekedar untuk hidup, sehingga manusia lebih terhormat dan mempunyai kedudukan yang lebih tinggi dari pada yang tidak berpendidikan. Pendidikan juga merupakan suatu unsur yang tidak dapat dipisahkan dari diri manusia. Mulai dari kandungan sampai beranjak dewasa kemudian tua manusia mengalami proses pendidikan yang didapatkan dari orang tua, masyarakat, maupun lingkungannya. Pendidikan bagaikan cahaya penerang yang berusaha menuntun manusia dalam menentukan arah, tujuan dan makna kehidupan ini. Masalah tentang kesejahteraan masyarakat telah diatur dalam Peraturan Daerah Kabupaten Padang Pariaman Nomor 5 Tahun 2016 yaitu pembangunan daerah dan perencanaan pembangunan daerah adalah pemanfaatan sumber daya yang dimiliki untuk peningkatan kesejahteraan masyarakat. Penelitian ini bertujuan : 1) Untuk mengetahui pengaruh variabel kebijakan publik terhadap kesejahteraan masyarakat di Kabupaten Padang Pariaman, 2) Untuk Mengetahui pengaruh variabel partisipasi masyarakat terhadap kesejahteraan masyarakat di Kabupaten Padang Pariaman, 3) Untuk Mengetahui pengaruh variabel tingkat pendidikan terhadap kesejahteraan masyarakat di Kabupaten Padang Pariaman.

\section{B. KAJIAN TEORI}

\section{Kesejahteraan Sosial}

Secara definitif, kesejahteraan sosial merupakan suatu kondisi atau keadaan sejahtera, baik fisik, mental maupun sosial, dan tidak hanya perbaikan terhadap penyakit sosial tertentu saja (Nursiah Chalid \& Yusbar Yusuf, 2014). Undang-undang Nomor 11 Tahun 2009 tentang Kesejahteraan Sosial menyebutkan kesejahteraan sosial adalah kondisi terpenuhinya kebutuhan material, spiritual, dan sosial warga negara agar dapat hidup layak dan mampu mengembangkan diri, sehingga dapat 
melaksanakan fungsi sosialnya. Menurut Suharto (2006), kesejahteraan sosial sedikitnya mengandung empat makna.

a. Kesejahteraan sosial sebagai kondisi sejahtera (well-being). Pengertian ini biasanya menunjuk pada istilah kesejahteraan sosial (social welfare) sebagai kondisi terpenuhinya kebutuhan materi dan nonmaterial. Midglye mendefinisikan kesejahteraan sosial sebagai a condition or state of human well-being. Kondisi sejahtera terjadi apabila kehidupan manusia aman dan bahagia karena kebutuhan dasar akan gizi, kesehatan, pendidikan, tempat tinggal dan pendapatan dapat dipenuhi, serta manakala manusia memperoleh perlindungan dari risiko-risiko utama yang mengancam kehidupannya.

b. Kesejahteraan sosial sebagai pelayanan sosial. Pelayanan sosial umumnya mencakup lima bentuk, yakni jaminan sosial (sosial security), pelayanan kesehatan, pendidikan, perumahan dan pelayanan sosial personal (personal social services).

c. Kesejahteraan sosial sebagai tunjangan sosial, khususnya diberikan kepada orang miskin.

d. Kesejahteraan sosial sebagai proses atau usaha terencana yang dilakukan oleh perorangan, lembaga-lembaga sosial, masyarakat maupun badan-badan pemerintah untuk meningkatkan kualitas kehidupan dan menyelenggarakan pelayanan sosial.

Dalam memahami realitas tingkat kesejahteraan, pada dasarnya terdapat beberapa faktor yang menyebabkan terjadinya kesenjangan tingkat kesejahteraan, antara lain sosial ekonomi rumah tangga atau masyarakat, struktur kegiatan ekonomi sektoral yang menjadi dasar kegiatan produksi rumah tangga atau masyarakat, potensial regional (sumber daya alam, lingkungan, dan infrastruktur) yang mempengaruhi perkembangan struktur kegiatan produksi, dan kondisi kelembagaan yang membentuk jaringan kerja produksi dan pemasaran pada skala lokal, regional, dan global (Taslim, 2004).

Indikator yang digunakan oleh para ilmuwan sosial untuk mengukur kondisi kesejahteraan sosial cukup beragam. Untuk melihat sejauh mana keberhasilan pembangunan dan kesejahteraan manusia, UNDP telah menerbitkan suatu indikator yaitu Indeks Pembangunan Manusia (IPM) untuk mengukur kesuksesan pembangunan dan kesejahteraan suatu negara. IPM adalah suatu tolak ukur angka kesejahteraan suatu daerah atau negara yang dilihat berdasarkan tiga dimensi yaitu: angka harapan hidup pada waktu lahir (life expectancy at birth), angka melek huruf (literacy rate) dan rata-rata lama sekolah (mean years of schooling), dan kemampuan daya beli (purchasing power parity). Indikator angka harapan hidup mengukur kesehatan, indikator angka melek huruf penduduk dewasa dan rata-rata lama sekolah mengukur pendidikan dan terakhir indikator daya beli mengukur standar hidup. Sedangkan dalam Peraturan Pemerintah Nomor 8 Tahun 2008 tentang Tahapan, Tatacara Penyusunan, Pengendalian, dan Evaluasi Pelaksanaan Rencana Pembangunan Daerah, indikator yang digunakan untuk mengukur kesejahteraan dan pemerataan ekonomi adalah 
laju pertumbuhan ekonomi, laju inflasi provinsi, PDRB per kapita, indeks gini, pemerataan pendapatan versi Bank Dunia, persentase penduduk di bawah garis kemiskinan dan angka kriminalitas yang tertangani. BPS mengukur kesejahteran rakyat melalui delapan bidang, yaitu kependudukan, kesehatan dan gizi, pendidikan, ketenagakerjaan, taraf dan pola konsumsi, perumahan dan lingkungan, kemiskinan, dan sosial lainnya.

Kemenkokesra menggambarkan kesejahteraan masyarakat berdasarkan kondisi dan realitas Indonesia dengan menggunakan tiga dimensi, yaitu dimensi keadilan sosial, keadilan ekonomi dan demokrasi. Di dalamnya terdapat dua puluh dua indikator yaitu akses listrik, akses berobat, rekreasi, lama sekolah, pemanfaatan jaminan sosial, usia harapan hidup, akses air bersih, akses sanitasi, tingkat pengeluaran perkapita, tingkat pemerataan pendapatan, kepemilikan rumah sendiri, bekerja, rasio pengeluaran terhadap garis kemiskinan, rasio PAD terhadap APBD, Akses terhadap sumber daya ekonomi, rasio biaya pendidikan terhadap total pengeluaran, rasio biaya kesehatan terhadap total pengeluaran, akses informasi, rasa aman, kebebasan sipil, hak politik, dan lembaga demokrasi.

Berdasarkan Undang-undang Nomor 11 Tahun 2009 tentang Kesejahteraan Sosial menyebutkan kesejahteraan sosial adalah kondisi terpenuhinya kebutuhan material, spiritual, dan sosial. Salah satu indikator untuk menilai aspek spiritual adalah menggunakan indeks kebahagiaan. Indeks kebahagiaan ini merupakan komposit dari berbagai indikator subyektif. Menurut BPS, indikator kebahagiaan meliputi pekerjaan, pendapatan rumah tangga, kondisi rumah dan aset, pendidikan, kesehatan, keharmonisan keluarga, hubungan sosial, ketersediaan waktu luang, kondisi lingkungan, dan kondisi keamanan.

Konsep kesejahteraan menurut (Nasikun, 1996) dapat dirumuskan sebagai padanan makna dari konsep martabat manusia yang dapat dilihat dari empat indikator yaitu : rasa aman (security), kesejahteraan (welfare), kebebasan (freedom), dan jati diri (identity). Badan Pusat Statistik (2000) menerangkan bahwa guna melihat tingkat kesejahteraan rumah tangga suatu wilayah ada beberapa indikator yang dapat dijadikan ukuran, antara lain tingkat pendapatan keluarga, komposisi pengeluaran rumah tangga dengan membandingkan pengeluaran untuk pangan dan non-pangan, tingkat pendidikan keluarga, tingkat kesehatan keluarga, dan kondisi perumahan serta fasilitas yang dimiliki dalam rumah tangga.

Menurut Bintarto (1989), kesejahteraan dapat diukur dari beberapa aspek kehidupan :

1) Dengan melihat kualitas hidup dari segi materi, seperti kualitas rumah, bahan pangan, dan sebagainya

2) Dengan melihat kualitas hidup dari segi fisik, seperti kesehatan tubuh, lingkungan alam, dan sebagainya

3) Dengan melihat kualitas hidup dari segi mental, seperti fasilitas pendidikan, lingkungan budaya, dan sebagainya

4) Dengan melihat kualitas hidup dari segi spiritual, seperti moral, etika, keserasian penyesuaian, dan sebagainya 
Kebahagiaan Nasional Bruto (Gross National Happiness) adalah ukuran kualitas dan kemapanan hidup yang dikembangkan oleh Pusat Studi Buthan, sebuah negara di benua Asia. Kualitas hidup diukur dengan dimensi yang lebih manusiawi dan komprehensif, tidak hanya didasarkan pada materi saja. Kebahagiaan nasional bruto dapat digunakan sebagai ukuran alternatif untuk mengukur keberhasilan pembangunan manusia. Ada sembilan ranah pengukuran yang kemudian dijabarkan menjadi tiga puluh tiga indikator. Ranah pengukuran dan indikatornya sebagaimana tersebut di bawah ini (Nursiah Chalid \& Yusbar Yusuf, 2014).

2. Kebijakan Publik

Menurut Chief J.O (1981) (Wahab, 2005), kebijakan publik adalah suatu tindakan bersanksi yang mengarah pada tujuan tertentu yang diarahkan pada suatu masalah tertentu yang saling berkaitan yang memengaruhi sebagian besar warga masyarakat. Menurut (Nugroho D., 2008), kebijakan publik adalah keputusan yang dibuat oleh negara, khususnya pemerintah, sebagai strategi untuk merealisasikan tujuan negara yang bersangkutan. Kebijakan Publik adalah strategi untuk mengantarkan masyarakat pada masa awal, memasuki masyarakat pada masa transisi, untuk menuju pada masyarakat yang dicita-citakan.

Karakteristik khusus dari kebijakan publik adalah bahwa keputusan politik tersebut dirumuskan oleh apa yang disebut Easton (Agustino, 2006) sebagai "otoritas" dalam sistem politik yaitu: "para senior, kepala tertinggi, eksekutif, legislatif, para hakim, administrator, penasehat, para raja, dan sebagainya." Selanjutnya Easton menyebutkan bahwa mereka-mereka yang berotoritas dalam sistem politik dalam rangka memformulasikan kebijakan publik itu adalah orang-orang yang terlibat dalam urusan sistem politik sehari-hari dan mempunyai tanggung jawab dalam suatu masalah tertentu di mana pada satu titik mereka diminta untuk mengambil keputusan di kemudian hari yang diterima serta mengikat sebagian besar anggota masyarakat selama waktu tertentu.

a. Tahap-tahap dalam Pembuatan Kebijakan Publik

Tahap-tahap pembuatan kebijakan publik menurut (William N.Dunn (2003) adalah sebagai berikut :

1) Penyusunan Agenda (Agenda Setting)

Agenda setting adalah sebuah fase dan proses yang sangat strategis dalam realitas kebijakan publik. Dalam proses inilah ada ruang untuk memaknai apa yang disebut sebagai masalah publik dan prioritas dalam agenda publik dipertarungkan. Jika sebuah isu berhasil mendapatkan status sebagai masalah publik, dan mendapatkan prioritas dalam agenda publik, maka isu tersebut berhak mendapatkan alokasi sumber daya publik yang lebih dari pada isu lain. Dalam agenda setting juga sangat penting untuk menentukan suatu isu publik yang akan diangkat dalam suatu agenda pemerintah. Issue kebijakan (policy issues) sering disebut juga sebagai masalah kebijakan (policy problem). Policy issues biasanya muncul karena telah terjadi silang pendapat di antara para aktor mengenai arah tindakan yang telah atau akan ditempuh, atau 
pertentangan pandangan mengenai karakter permasalahan tersebut. Menurut William N.Dunn (1999), isu kebijakan merupakan produk atau fungsi dari adanya perdebatan baik tentang rumusan, rincian, penjelasan maupun penilaian atas suatu masalah tertentu. Namun tidak semua isu bisa masuk menjadi suatu agenda kebijakan.

2) Formulasi Kebijakan

Masalah yang sudah masuk dalam agenda kebijakan kemudian dibahas oleh para pembuat kebijakan. Masalah-masalah tadi didefinisikan untuk kemudian dicari pemecahan masalah yang terbaik. Pemecahan masalah tersebut berasal dari berbagai alternatif atau pilihan kebijakan yang ada. Sama halnya dengan perjuangan suatu masalah untuk masuk dalam agenda kebijakan, dalam tahap perumusan kebijakan masing-masing alternatif bersaing untuk dapat dipilih sebagai kebijakan yang diambil untuk memecahkan masalah.

3) Adopsi/ Legitimasi Kebijakan

Tujuan legitimasi adalah untuk memberikan otorisasi pada proses dasar pemerintahan. Jika tindakan legitimasi dalam suatu masyarakat diatur oleh kedaulatan rakyat, warga negara akan mengikuti arahan pemerintah. Namun warga negara harus percaya bahwa tindakan pemerintah yang sah harus didukung. Legitimasi dapat dikelola melalui manipulasi simbol-simbol tertentu, dimana melalui proses ini, warga negara belajar untuk mendukung pemerintah.

4) Implementasi Kebijakan

Kebijakan yang telah diambil, dilaksanakan oleh unit-unit administrasi yang memobilisasi sumber daya finansial dan manusia.

5) Penilaian / Evaluasi Kebijakan

Evaluasi kebijakan dapat dikatakan sebagai kegiatan yang menyangkut estimasi atau penilaian kebijakan yang mencakup substansi, implementasi dan dampak. Dalam hal ini, evaluasi dipandang sebagai suatu kegiatan fungsional. Artinya, evaluasi kebijakan tidak hanya dilakukan pada tahap akhir saja, melainkan dilakukan dalam seluruh proses kebijakan. Dengan demikian, evaluasi kebijakan bisa meliputi tahap perumusan masalah-masalah kebijakan programprogram yang diusulkan untuk menyelesaikan masalah kebijakan, implementasi, maupun tahap dampak kebijakan.

b. Implementasi Kebijakan Model George Edwards III

Teori yang dikemukakan oleh Edwards ini disebut juga dengan Direct and Indirect Impact on Implementation. Menurut Edwards, ada 4 (empat) faktor yang memengaruhi implementasi suatu kebijakan yang antara satu faktor dengan faktor lain saling memengaruhi, yaitu:

1) Faktor Komunikasi

Suatu program hanya dapat dilaksanakan dengan baik apabila jelas bagi para pelaksana. Hal ini menyangkut proses penyampaian informasi, kejelasan informasi dan konsistensi informasi yang disampaikan (Akib, 2010). Semua hal tersebut dapat diperoleh melalui komunikasi yang efektif. Ada beberapa hal yang memengaruhi komunikasi, yaitu : 
a) Transmisi; penyaluran komunikasi yang baik akan dapat menghasilkan suatu implementasi yang baik pula. Seringkali terjadi hambatan dalam mentransmisikan perintah-perintah implementasi. Hambatan-hambatan tersebut dapat terjadi antara lain karena adanya pertentangan pendapat antara pelaksana dengan perintah yang dikeluarkan oleh pengambil kebijakan, penyampaian informasi yang melewati berlapis-lapis hierarki birokrasi dan adanya persepsi dan ketidakmauan para pelaksana untuk mengetahui persyaratan suatu kebijakan (Winarno, 2012).

b) Kejelasan; komunikasi yang diterima oleh implementor haruslah jelas, akurat, dan tidak membingungkan, sehingga dapat dihindari terjadinya interpretasi yang salah. Menurut Edwards ada 6 faktor yang mendorong ketidakjelasan komunikasi kebijakan, yaitu: kompleksitas kebijakan publik, keinginan untuk tidak mengganggu kelompok-kelompok masyarakat, kurangnya konsensus mengenai tujuan-tujuan kebijakan, masalah-masalah dalam memulai suatu kebijakan baru, menghindari pertanggungjawaban kebijakan dan sifat pembentukan kebijakan pengadilan (Winarno, 2012).

c) Konsistensi; perintah-perintah yang diberikan harus konsisten dan jelas karena perintah yang tidak konsisten akan mendorong pelaksana mengambil tindakan yang sangat longgar dalam menafsirkan dan mengimplementasikan kebijakan.

Dari penjelasan tersebut dapat disimpulkan bahwa semakin cermat keputusan dan perintah pelaksanaan diteruskan kepada pelaksana, maka semakin tinggi probabilitas keputusan dan perintah kebijakan tersebut untuk dilaksanakan dengan baik (Winarno, 2012).

2) Faktor Sumber daya

Walaupun isi kebijakan sudah dikomunikasikan dengan jelas dan konsisten, tetapi apabila implementor kekurangan sumberdaya untuk melaksanakan, maka implementasi tidak akan berjalan efektif (Subarsono, 2009). Indikator untuk menilai kecukupan sumberdaya adalah:

a) Staf; sumber daya yang paling esensial dalam mengimplementasikan kebijakan adalah staf. Sumberdaya yang efektif tidak hanya dinilai dari sisi jumlah staf namun juga kompetensi atau kecakapan sumber daya manusianya.

b) Informasi; dalam mengimplementasikan suatu kebijakan, informasi ada dalam 2 bentuk. Pertama, informasi mengenai bagaimana melaksanakan suatu kebijakan. Kedua, data dalam bentuk peraturan pemerintah. Para implementor mesti mengetahui apakah orang lain yang terlibat didalam mengimplementasikan kebijakan melengkapi undang-undang yang diperlukan sebagai dasar legitimasi.

c) Wewenang; kewenangan merupakan otoritas atau legitimasi bagi para pelaksana dalam melaksanakan kebijakan yang telah ditetapkan secara politik. Kewenangan harus bersifat formal untuk menghindari 
gagalnya proses implementasi karena dipandang oleh publik implementor tersebut tidak terlegitimasi.

3) Faktor Disposisi

Disposisi diartikan sebagai sikap atau perspektif implementor dalam melaksanakan kebijakan. Jika para implementor bersikap baik atau mendukung suatu kebijakan maka kemungkinan besar mereka akan melaksanakan kebijakan sebagaimana yang diinginkan oleh pembuat kebijakan. Namun sebaliknya, bila tingkah laku atau perspektif implementor berbeda dengan pembuat kebijakan maka proses pelaksanaan suatu kebijakan akan sulit. Beberapa hal penting yang harus diperhatikan berkaitan dengan disposisi ini adalah :

a) Pengangkatan birokrat; dalam memilih atau mengangkat pejabat pelaksana kebijakan sebaiknya berdasarkan kemampuan atau kapabilitas bukan berdasarkan atas kepentingan-kepentingan lain. Karena personil yang tidak mendukung akan menghambat dalam pelaksanaan kebijakan.

b) Insentif; mengubah personil dalam birokrasi pemerintah merupakan pekerjaan yang sulit dan tidak menjamin proses implementasi dapat berjalan lancar. Salah satu teknik yang dikemukakan Edwards adalah dengan memanipulasi insentif. Dengan memberikan insentif diharapkan akan menjadi faktor pendorong yang membuat implementor melaksanakan perintah dengan baik. Hal ini dilakukan sebagai upaya memenuhi kepentingan-kepentingan pribadi (selfinterest), organisasi atau kebijakan substantif.

4) Faktor Struktur Birokrasi

Pada dasarnya, para implementor mungkin mengetahui apa yang harus dilakukan dalam pelaksanaan kebijakan serta mempunyai cukup sumber daya dan keinginan namun terkadang mereka masih terhambat dengan struktur birokrasi dimana mereka menjalankan kegiatan tersebut. Menurut Edwards III ada 2 karakteristik yang dapat meningkatkan kinerja struktur birokrasi, yaitu membuat Standard Operating Procedures (SOP) dan fragmentasi (Winarno, 2012) dan (Tangkilisan, 2003).

3. Partisipasi Masyarakat

Partisipasi masyarakat menekankan pada "partisipasi" langsung warga dalam pengambilan keputusan pada lembaga dan proses kepemerintahan. Gaventa dan Valderma dalam Siti Irene Astuti D. (2009:34-35) menegaskan bahwa partisipasi masyarakat telah mengalihkan konsep partisipasi menuju suatu kepedulian dengan berbagai bentuk keikutsertaan warga dalam pembuatan kebijaksanaan dan pengambilan keputusan di berbagai gelanggang kunci yang mempengaruhi kehidupan warga masyarakat. Pengembangan konsep dan asumsi dasar untuk meluangkan gagasan dan praktik tentang partisipasi masyarakat meliputi : 
1) Partisipasi merupakan hak politik yang melekat pada warga sebagaimana hak politik lainnya. Hak itu tidak hilang ketika ia memberikan mandat pada orang lain untuk duduk dalam lembaga pemerintahan. Sedangkan hak politik, sebagai hak asasi, tetap melekat pada setiap individu yang bersangkutan.

2) Partisipasi langsung dalam pengambilan keputusan mengenai kebijakan publik di lembaga-lembaga formal dapat untuk menutupi kegagalan demokrasi perwakilan. Demokrasi perwakilan masih menyisakan beberapa kelemahan yang ditandai dengan keraguan sejauh mana orang yang dipilih dapat merepresentasikan kehendak masyarakat.

3) Partisipasi masyarakat secara langsung dalam pengambilan keputusan publik dapat mendorong partisipasi lebih bermakna. Partisipasi dilakukan secara sistematik, bukan hal yang insidental

4) Berkaitan dengan diterimanya desentralisasi sebagai instrumen yang mendorong tata pemerintahan yang baik (good governance).

5) Partisipasi masyarakat dapat meningkatkan kepercayaan publik terhadap penyelenggaraan dan lembaga pemerintahan. Demokratisasi dan desentralisasi di negara berkembang termasuk Indonesia terjadi dalam situasi rendahnya kepercayaan masyarakat terhadap penyelenggaraan dan lembaga pemerintah. Dengan melibatkan warga dalam proses pengambilan keputusan maka diharapkan kepercayaan publik terhadap pemerintah dapat terus ditingkatkan, dan meningkatnya kepercayaan warga dipercaya sebagai indikator penting bagi menguatnya dukungan dan keabsahan pemerintah yang berkuasa.

Partisipasi masyarakat merupakan keterlibatan anggota masyarakat dalam pembangunan dan pelaksanaan (implementasi) program atau proyek pembangunan yang dilakukan dalam masyarakat lokal. Partisipasi masyarakat memiliki ciri-ciri bersifat proaktif dan bahkan reaktif (artinya masyarakat ikut menalar baru bertindak), ada kesepakatan yang dilakukan oleh semua yang terlibat, ada tindakan yang mengisi kesepakatan tersebut, ada pembagian kewenangan dan tanggung jawab dalam kedudukan yang setara.

Oakley (1991:9) memberi pemahaman tentang konsep partisipasi, dengan mengelompokkan ke dalam tiga pengertian pokok, yaitu Partisipasi sebagai kontribusi; Partisipasi sebagai organisasi; dan Partisipasi sebagai pemberdayaan. Dengan landasan teori dari Oakley, disusun definisi konseptual variabel Partisipasi Masyarakat adalah keterlibatan langsung masyarakat dalam penanganan masalah kebersihan lingkungan yang meliputi kontribusi masyarakat, pengorganisasian masyarakat dan pemberdayaan masyarakat dalam penanganan masalah kebersihan lingkungan. Dari definisi konseptual tersebut diperoleh 3 (tiga) dimensi kajian, yakni Dimensi Kontribusi Masyarakat, Dimensi Pengorganisasian Masyarakat, dan Dimensi Pemberdayaan Masyarakat. Dimensi Kontribusi Masyarakat dijabarkan menjadi indikator-indikator : (1) Kontribusi Pemikiran, (2) Kontribusi Dana, (3) Kontribusi Tenaga, dan (4) Kontribusi Sarana. Dimensi Pengorganisasian Masyarakat dijabarkan menjadi 
indikator-indikator : (5) Model Pengorganisasian, (6) Struktur Pengorganisasian, (7) Unsur-unsur Pengorganisasian, dan (8) Fungsi Pengorganisasian.. Dimensi Pemberdayaan Masyarakat dijabarkan menjadi indikator-indikator : (9) Peran Masyarakat, (10) Aksi Masyarakat, (11) Motivasi Masyarakat, dan (12) Tanggungjawab Masyarakat.

\section{Tingkat Pendidikan}

Tingkat atau jenjang pendidikan adalah tahap pendidikan yang berkelanjutan, yang ditetapkan berdasarkan tingkat perkembangan peserta didik, tingkat kerumitan bahan pengajaran dan cara menyajikan bahan pengajaran (Ihsan, 2010).

Menurut UU Sistem Pendidikan Nasional No. 20 Tahun 2003 menjelaskan bahwa indikator tingkat pendidikan terdiri dari jenjang pendidikan dan kesesuaian jurusan. Jenjang pendidikan adalah tahapan pendidikan yang ditetapkan berdasarkan tingkat perkembangan peserta didik, tujuan yang akan dicapai, dan kemampuan yang dikembangkan, yaitu terdiri dari:

1) Pendidikan dasar

Jenjang pendidikan awal selama 9 (sembilan) tahun pertama masa sekolah anak-anak yang melandasi jenjang pendidikan menengah.

Pendidikan dasar terdiri dari :

a) Sekolah Dasar atau Madrasah Ibtidaiyah

b) SMP atau MTs

Menurut Ihsan (2010) Pendidikan dasar diselenggarakan untuk memberikan bekal dasar yang diperlukan untuk hidup dalam masyarakat, berupa pengembangan sikap, pengetahuan, dan keterampilan dasar.

2) Pendidikan menengah

Jenjang pendidikan lanjutan pendidikan dasar. Pendidikan menengah terdiri dari:

a) SMA dan MA

b) SMK dan MAK

Menurut Ihsan (2010) Pendidikan menengah dalam hubungan kebawah berfungsi sebagai lanjutan dan perluasan pendidikan dasar. Adapun dalam hubungan keatas mempersiapkan peserta didik untuk mengikuti pendidikan tinggi ataupun memasuki lapangan kerja.

\section{3) Pendidikan tinggi}

Jenjang pendidikan setelah pendidikan menengah yang mencakup program sarjana, magister, doktor, dan spesialis yang diselenggarakan oleh perguruan tinggi.

Pendidikan tinggi terdiri atas:

a) Akademik

b) Institut

c) Sekolah Tinggi

Menurut Ihsan (2010) Pendidikan tinggi merupakan kelanjutan dari pendidikan menengah, yang diselenggarakan untuk menyiapkan peserta didik menjadi anggota masyarakat yang memiliki kemampuan akademik 
dan/ atau profesional yang dapat menerapkan, mengembangkan dan/ atau menciptakan ilmu pengetahuan, teknologi dan/atau kesenian.

Dari uraian diatas jenjang persekolahan atau tingkat-tingkat yang ada pada pendidikan formal dimengerti bahwa pendidikan merupakan proses yang berkelanjutan. Oleh karena itu setiap jenjang atau tingkat pendidikan itu harus dilaksanakan secara tertib, dalam arti tidak bisa terbalik penempatannya. Setiap jenjang atau tingkatan mempunyai tujuan dan materi pelajaran yang berbeda-beda. Perbedaan luas dan kedalaman materi ajaran tersebut jelas akan membawa pengaruh terhadap kualitas lulusannya, baik ditinjau dari segi pengetahuan, kemampuan, sikap maupun kepribadiannya. Manusia memerlukan pengetahuan, ketrampilan, penguasaan teknologi, dan dapat mandiri memalui pendidikan. Produktivitas kerja memerlukan pengetahuan, ketrampilan dan penguasaan teknologi. Sehingga dengan adanya tingkat pendidikan karyawan maka kinerja karyawan akan menjadi lebih baik dan tujuan dari perusahaan akan tercapai dengan sempurna (Drs. Uyoh Sadulloh, 2011).

\section{METODE PENELITIAN}

Sugiyono (2014:2) mengemukakan secara umum metode penelitian diartikan sebagai cara ilmiah untuk mendapatkan data dengan tujuan dan kegunaan tertentu. Dalam melakukan suatu penelitian hendaknya menentukan terlebih dahulu metode penelitian yang kita teliti. Penelitian yang dilakukan ini bertujuan untuk mengetahui pengaruh kebijakan publik, partisipasi masyarakat dan tingkat pendidikan terhadap kesejahteraan masyarakat. Berdasarkan tujuan penelitian yang telah disebutkan, maka metode yang digunakan pada penelitian ini adalah metode kuantitatif asosiatif. Data merupakan keterangan yang dapat memberikan gambaran atas suatu keadaan. Jenis data yang digunakan dalam penelitian ini adalah data primer, cara memperolehnya dengan menyebarkan kuesioner kepada pihak yang bersangkutan. Jadi data bersumber pada informasi yang diberikan oleh masyarakat Kecamatan Sungai Limau Kabupaten Padang Pariaman.

Menurut Arikunto (2006:130) "Populasi adalah keseluruhan subjek penelitian". Dalam penelitian ini yang menjadi populasi adalah jumlah kepala keluarga yang ada di Kecamatan Sungai Limau 10048 Kepala Keluarga.

\section{HASIL}

\section{Uji Normalitas}

Hasil uji persyaratan normalitas data penelitian, dilakukan dengan menggunakan teknik uji Kolmogrov Smirnov (Uji K-S) sebagai dasar penolakan atau penerimaan keputusan normal atau tidaknya distribusi data sampel penelitian. Sebagaimana telah dijelaskan pada Bab. III, dimana data uji normalitas ditetapkan pada signifikansi alpha $(\alpha=0,05)$. Berikut, data hasil perhitungan uji normalitas disajikan pada Tabel 8 berikut :

Tabel 1. Hasil Uji Normalitas

One-Sample Kolmogorov-Smirnov Test

Unstandardized Residual 


\begin{tabular}{llr} 
Normal Parameters $\mathrm{a}, \mathrm{b}$ & Mean & 0.0000000 \\
\cline { 2 - 3 } & Std. Deviation & 4.35961363 \\
\hline Most Extreme Differences & Absolute & 0.059 \\
\cline { 2 - 3 } & Positive & 0.059 \\
\cline { 2 - 3 } & Negative & -0.050 \\
\hline Test Statistic & & 0.059 \\
\hline Asymp. Sig. (2-tailed) & & $.200^{\mathrm{c}, \mathrm{d}}$ \\
\hline
\end{tabular}

Informasi data Tabel 8 diketahui bahwa nilai signifikansi variabel kebijakan publik, partispasi masyarakat, tingkat pendidikan dan kesejahteraan masyarakat dengan Asymp. Sig sebesar 0,200. Semua variabel lebih besar dari taraf alpha 0,05 yang menunjukan bahwa sebaran data variabel kebijakan publik, partispasi masyarakat, tingkat pendidikan dan kesejahteraan masyarakat dinyatakan normal.

\section{Uji Multikolinearitas}

Uji multikolinieritas bertujuan untuk menguji apakah model regresi ditemukan adanya korelasi di antara variabel bebas. Jika variabel bebas saling berkorelasi, maka variabel-variabel ini tidak ortogonal. Variabel ortogonal adalah variabel bebas yang nilai korelasi antar sesama variabel bebas sama dengan nol. Untuk mendeteksi ada atau tidaknya multikolinieritas di dalam model regresi adalah sebagai berikut :

Tabel 2. Hasil Uji Multikolinearitas

\begin{tabular}{|c|l|c|c|c|c|}
\hline No & \multicolumn{1}{|c|}{ Variabel } & $\begin{array}{c}\text { Nilai } \\
\text { VIF }\end{array}$ & Toleransi & $\begin{array}{c}\text { Batas } \\
\text { VIF }\end{array}$ & Keterangan \\
\hline 1 & Kebijakan Publik (X1) & 1.247 & 0.802 & 10 & $\begin{array}{c}\text { Tidak Terjadi } \\
\text { Multikolinearitas }\end{array}$ \\
\hline 2 & Partisipasi Masyarakat (X2) & 1.480 & 0.676 & 10 & $\begin{array}{c}\text { Tidak Terjadi } \\
\text { Multikolinearitas }\end{array}$ \\
\hline 3 & Tingkat Pendidikan (X3) & 1.415 & 0.707 & 10 & $\begin{array}{c}\text { Tidak Terjadi } \\
\text { Multikolinearitas }\end{array}$ \\
\hline
\end{tabular}

Hasil perhitungan nilai toleransi yang menunjukkan tidak ada variabel bebas yang memiliki nilai tolerance kurang dari $10 \%$ yang berarti tidak ada korelasi antar variabel bebas yang nilainya lebih dari $90 \%$. Hasil perhitungan nilai variance inflation factor (VIF) juga menunjukkan hal yang sama tidak ada satu variabel bebas yang memiliki nilai VIF lebih dari 10. Jadi dapat disimpulkan bahwa tidak ada multikolinieritas antar variabel bebas dalam model regresi.

\section{Uji Heterokedastisitas}

Uji heterokedastisitas digunakan untuk menguji apakah terjadi ketidaksamaan varians dari residual satu pengamatan ke pengamatan lain. Apabila terjadi heterokedastisitas, hal ini menunjukkan varians residual tidak sama atau tetap sehingga penggunaan regresi menjadi tidak efesien. Model regresi yang baik adalah homokedastisitas atau bebeas dari gejala heterokedastisitas. Uji heterokedastisitas dapat dilakukan dengan metode korelasi spearman. Pada dasarnya uji heterokedastisitas dilakukan untuk mengetahui apakah antar predictor mempunyai pengaruh yang signifikan dengan nilai residualnya. Residual yang normal adalah yang memiliki nilai signifikan $>0,05$. Untuk lebih jelasnya dapat dijelaskan pada tabel berikut : 
Tabel 3. Hasil Uji Heterokedastisitas

\begin{tabular}{|c|l|c|c|c|}
\hline No & \multicolumn{1}{|c|}{ Variabel } & Nilai Sig. & Batas Sig. & Keterangan \\
\hline 1 & Kebijakan Publik (X1) & 0.656 & 0,05 & Tidak Terjadi Heterokedastisitas \\
\hline 2 & Partisipasi Masyarakat (X2) & 0.418 & 0,06 & Tidak Terjadi Heterokedastisitas \\
\hline 3 & Tingkat Pendidikan (X3) & 0.390 & 0,05 & Tidak Terjadi Heterokedastisitas \\
\hline
\end{tabular}

Berdasarkan Tabel di atas untuk variabel kebijakan publik (X1) sebesar 0,656 dengan nilai signifikansi lebih besar dari $0,05(0,656>0,05)$ maka dinyatakan data kebijakan publik (X1) adalah homogen, selanjutnya, untuk variabel partisipasi msyarakat (X2) diperoleh sebesar 0,418 dengan nilai signifikan lebih besar dari 0,05 yang berarti $(0,418>0,05)$ dan variabel ini berarti memiliki varians yang homogen. Selanjutnya untuk variabel tingkat pendidikan (X3) sebesar 0,390 dengan signifikansi lebih besar dari $0,05(0,390>0,05)$ dan variabel ini berarti memiliki varians yang homogen.

\section{Uji Hipotesis}

a. Uji F

Uji $\mathrm{F}$ digunakan untuk mengetahui apakah variabel-variabel independen secara simultan berpengaruh signifikan terhadap variabel dependen. Derajat kepercayaan yang digunakan adalah 0,05. Apabila nilai $F$ hasil perhitungan lebih besar daripada nilai F menurut tabel maka hipotesis alternatif, yang menyatakan bahwa semua variabel independen secara simultan berpengaruh signifikan terhadap variabel dependen. Untuk analisisnya dari output SPSS dapat dilihat dari tabel dibawah ini:

Tabel 4. Hasil Uji Simultan (F)

\begin{tabular}{|c|c|c|c|c|c|c|}
\hline \multicolumn{7}{|c|}{ Model Summary } \\
\hline Model & $\mathrm{R}$ & R Square & Adjusted R Square & Std. Error of the Estimate & & \\
\hline 1 & $.656^{\mathrm{a}}$ & 0.430 & 0.412 & 4.428 & & \\
\hline \multicolumn{7}{|c|}{$\begin{array}{l}\text { a. Predictors: (Constant), Tingkat Pendidikan (X3), Kebijakan Publik (X1), Partisipasi Masyarakat (X2) } \\
\text { ANOVA }^{\mathrm{a}}\end{array}$} \\
\hline Model & & Sum of Squares & df & Mean Square & $\mathrm{F}$ & Sig. \\
\hline \multirow[t]{3}{*}{1} & Regression & 1406.076 & 3 & 468.692 & 23.905 & $.000^{\mathrm{b}}$ \\
\hline & Residual & 1862.611 & 95 & 19.606 & & \\
\hline & Total & 3268.687 & 98 & & & \\
\hline
\end{tabular}

Pada tabel Model Summary dapat dilihat pada kolom Adjusted R Square adalah sebesar 0,412. Hal ini berarti secara simultan kontribusi variabel pengaruh kebijakan publik (X1), partisipasi masyarakat (X2) dan tingkat pendidikan (X3) memiliki kontribusi terhadap kesejahteraan masyarakat Kabupaten Padang Pariaman (Y) sebesar 0,412 atau 41,2\% yang berarti sisanya $58,8 \%$ dipengaruhi oleh variabel lain.

Dari tabel Anova diperoleh nilai Fhitung sebesar 23,905 dengan nilai probabilitas $(\mathrm{sig})=0,000$. Nilai Fhitung 23,905>Ftabel 2,700 ( Ftabel lihat pada lampiran), dan nilai sig. lebih kecil dari nilai probabilitas 0,05 atau nilai $0,000<0,05$; maka $\mathrm{H} 1$ diterima, berarti secara bersama-sama (simultan) kebijakan publik (X1), partisipasi masyarakat (X2) dan tingkat pendidikan (X3) berpengaruh signifikan terhadap kesejahteraan masyarakat Kabupaten Padang Pariaman (Y).

Uji Parsial Variabel Kebijakan Publik (X1) Terhadap Kesejahteraan Masyarakat Kabupaten Padang Pariaman (Y) 
Untuk mengetahui pengaruh variabel Kebijakan Publik (X1) Terhadap Kesejahteraan Masyarakat Kabupaten Padang Pariaman (Y) dapat dijelaskan pada tabel berikut :

Tabel. 5. Uji Parsial Variabel Kebijakan Publik (X1) Terhadap Kesejahteraan Masyarakat Kabupaten Padang Pariaman (Y) Model Summary

\begin{tabular}{|c|c|c|c|c|c|c|}
\hline Model & $\mathrm{R}$ & R Square & $\begin{array}{l}\text { Adjusted R } \\
\text { Square }\end{array}$ & $\begin{array}{l}\text { Std. Error of the } \\
\text { Estimate }\end{array}$ & & \\
\hline 1 & $.531^{\mathrm{a}}$ & 0.282 & 0.275 & 4.918 & & \\
\hline \multicolumn{7}{|c|}{ a. Predictors: (Constant), Kebijakan Publik (X1) } \\
\hline \multicolumn{7}{|c|}{ ANOVA $^{a}$} \\
\hline Model & & $\begin{array}{l}\text { Sum of } \\
\text { Squares }\end{array}$ & df & Mean Square & $F$ & Sig. \\
\hline \multirow[t]{3}{*}{1} & Regression & 922.287 & 1 & 922.287 & 38.127 & $.000^{\mathrm{b}}$ \\
\hline & Residual & 2346.400 & 97 & 24.190 & & \\
\hline & Total & 3268.687 & 98 & & & \\
\hline
\end{tabular}

a. Dependent Variable: Kesejahteraan Masyarakat $(\mathrm{Y})$

b. Predictors: (Constant), Kebijakan Publik (X1)

\section{Coefficients $^{a}$}

\begin{tabular}{|c|c|c|c|c|c|c|}
\hline \multirow{2}{*}{\multicolumn{2}{|c|}{ Model }} & \multicolumn{2}{|c|}{ Unstandardized Coefficients } & \multirow{2}{*}{$\begin{array}{c}\text { Standardized } \\
\text { Coefficients } \\
\text { Beta } \\
\end{array}$} & \multirow[b]{2}{*}{$\mathrm{t}$} & \multirow[b]{2}{*}{ Sig. } \\
\hline & & B & Std. Error & & & \\
\hline \multirow[t]{2}{*}{1} & (Constant) & 23.869 & 4.184 & & 5.705 & 0.000 \\
\hline & $\begin{array}{l}\text { Kebijakan } \\
\text { Publik (X1) }\end{array}$ & 0.477 & 0.077 & 0.531 & 6.175 & 0.000 \\
\hline
\end{tabular}

a. Dependent Variable: Kesejahteraan Masyarakat (Y)

Pada tabel di atas variabel kebijakan publik (X1) diperoleh nilai $=$ 6,175 dengan signifikansi 0,000 dimana $0,000<0,05$ sehingga $\mathrm{H} 0$ ditolak dan Ha diterima yaitu yang berbunyi "ada pengaruh kebijakan publik (X1) secara signifikan terhadap Kesejahteraan Masyarakat Kabupaten Padang Pariaman (Y)". Pada tabel Model Summary dapat dilihat dari kolom Adjusted R Square sebesar 0,275. Hal ini berarti bahwa variabel kebijakan publik (X1) mempunyai kontribusi sebesar 0,275 atau 27,5\% terhadap Kesejahteraan Masyarakat Kabupaten Padang Pariaman (Y)

Uji Parsial Variabel Partisipasi Masyarakat (X2) Terhadap Kesejahteraan Masyarakat Kabupaten Padang Pariaman (Y)

Untuk mengetahui pengaruh variabel Partisipasi Masyarakt (X2) Terhadap Kesejahteraan Masyarakat Kabupaten Padang Pariaman (Y) dapat dijelaskan pada tabel berikut :

Tabel. 6. Uji Parsial Variabel Partisipasi Masyarakat (X2) Terhadap Kesejahteraan Masyarakat Kabupaten Padang Pariaman Model Summary

\begin{tabular}{|c|c|c|c|c|c|c|}
\hline Model & $\mathrm{R}$ & R Square & $\begin{array}{l}\text { Adjusted R } \\
\text { Square }\end{array}$ & $\begin{array}{l}\text { Std. Error of the } \\
\text { Estimate }\end{array}$ & & \\
\hline 1 & $.512^{\mathrm{a}}$ & 0.262 & 0.255 & 4.986 & & \\
\hline \multicolumn{7}{|c|}{ a. Predictors: (Constant), Partisipasi Masyarakat (X2) } \\
\hline \multicolumn{7}{|c|}{ ANOVA $^{a}$} \\
\hline Model & & $\begin{array}{l}\text { Sum of } \\
\text { Squares }\end{array}$ & df & Mean Square & $\mathrm{F}$ & Sig. \\
\hline 1 & Regression & 857.118 & 1 & 857.118 & 34.476 & $.000^{\mathrm{b}}$ \\
\hline
\end{tabular}




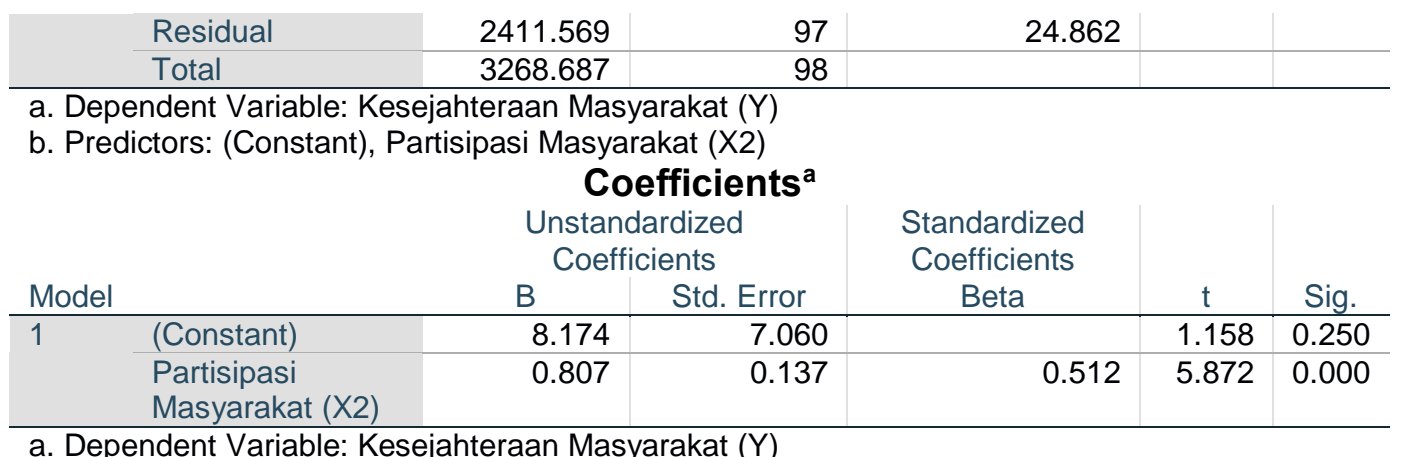

Pada tabel di atas variabel partispasi masyarkat (X2) diperoleh nilai $=5,872$ dengan signifikansi 0,000 dimana $0,000<0,05$ sehingga H0 ditolak dan Ha diterima yaitu yang berbunyi "ada pengaruh partisipasi masyarakat (X2) secara signifikan terhadap Kesejahteraan Masyarakat Kabupaten Padang Pariaman (Y)". Pada tabel Model Summary dapat dilihat dari kolom Adjusted R Square sebesar 0,255. Hal ini berarti bahwa variabel partisispasi masyarakat (X2) mempunyai kontribusi sebesar 0,255 atau $25,5 \%$ terhadap Kesejahteraan Masyarakat Kabupaten Padang Pariaman (Y)

Uji Parsial Variabel Tingkat Pendidikan (X3) Terhadap Kesejahteraan Masyarakat Kabupaten Padang Pariaman (Y)

Untuk mengetahui pengaruh variabel Tingkat Pendidikan (X3) Terhadap Kesejahteraan Masyarakat Kabupaten Padang Pariaman (Y) dapat dijelaskan pada tabel berikut :

Tabel. 7. Uji Parsial Variabel Tingkat Pendidikan (X3) Terhadap Kesejahteraan Masyarakat Kabupaten Padang Pariaman (Y) Model Summary

\begin{tabular}{|c|c|c|c|c|c|c|}
\hline \multicolumn{7}{|c|}{ Model Summary } \\
\hline Model & $\mathrm{R}$ & R Square & $\begin{array}{l}\text { Adjusted R } \\
\text { Square }\end{array}$ & \multicolumn{3}{|l|}{$\begin{array}{l}\text { Std. Error of the } \\
\text { Estimate }\end{array}$} \\
\hline 1 & $.498^{\mathrm{a}}$ & 0.248 & 0.240 & 5.034 & & \\
\hline \multicolumn{7}{|c|}{ a. Predictors: (Constant), Tingkat Pendidikan (X3) } \\
\hline \multicolumn{7}{|c|}{ ANOVA $^{a}$} \\
\hline \multicolumn{2}{|l|}{ Model } & $\begin{array}{l}\text { Sum of } \\
\text { Squares }\end{array}$ & df & Mean Square & $\mathrm{F}$ & Sig. \\
\hline \multirow[t]{3}{*}{1} & Regression & 810.380 & 1 & 810.380 & 31.976 & $.000^{\mathrm{b}}$ \\
\hline & Residual & 2458.307 & 97 & \multirow[t]{2}{*}{25.343} & & \\
\hline & Total & 3268.687 & 98 & & & \\
\hline \multicolumn{7}{|c|}{$\begin{array}{l}\text { a. Dependent Variable: Kesejahteraan Masyarakat }(\mathrm{Y}) \\
\text { b. Predictors: (Constant), Tingkat Pendidikan (X3) }\end{array}$} \\
\hline & & \multicolumn{2}{|c|}{ Unstandardized Coefficients } & \multirow{2}{*}{$\begin{array}{c}\text { Standardized } \\
\text { Coefficients } \\
\text { Beta }\end{array}$} & \multirow[b]{2}{*}{ t } & \multirow[b]{2}{*}{ Sig. } \\
\hline Model & & B & Std. Error & & & \\
\hline \multirow[t]{2}{*}{1} & (Constant) & 36.386 & 2.378 & & 15.301 & 0.000 \\
\hline & $\begin{array}{l}\text { Tingkat Pendidikan } \\
\text { (X3) }\end{array}$ & 3.061 & 0.541 & 0.498 & 5.655 & 0.000 \\
\hline
\end{tabular}


a. Dependent Variable: Kesejahteraan Masyarakat $(\mathrm{Y})$

Pada tabel di atas variabel tingkat pendidikan (X3) diperoleh nilai $=5,655$ dengan signifikansi 0,000 dimana 0,000<0,05 sehingga $\mathrm{H} 0$ ditolak dan Ha diterima yaitu yang berbunyi "ada pengaruh tingkat pendidikan (X2) secara signifikan terhadap Kesejahteraan Masyarakat Kabupaten Padang Pariaman (Y)". Pada tabel Model Summary dapat dilihat dari kolom Adjusted R Square sebesar 0,240. Hal ini berarti bahwa variabel tingkat pendidikan (X3) mempunyai kontribusi sebesar 0,240 atau 24\% terhadap Kesejahteraan Masyarakat Kabupaten Padang Pariaman (Y)

\section{b. Uji Koefisien Determinasi}

Koefisien determinasi (r2) berguna untuk menunjukkan seberapa besar kontribusi variabel bebas terhadap variabel terikat. Selanjutnya untuk lebih jelasnya dapat dilihat pada tabel berikut :

Tabel 8. Uji Koefisien Determinasi

\section{Model Summary}

\begin{tabular}{llrrr} 
Model & $\mathrm{R}$ & $\mathrm{R}$ Square & Adjusted R Square & Std. Error of the Estimate \\
\hline 1 & $.656^{\mathrm{a}}$ & 0.430 & 0.412 & 4.428 \\
\hline \multicolumn{4}{l}{$\begin{array}{l}\text { a. Predictors: (Constant), Tingkat Pendidikan (X3), Kebijakan Publik (X1), Partisipasi Masyarakat } \\
\text { (X2) }\end{array}$}
\end{tabular}

Berdasarkan Tabel di atas, dapat dilihat nilai Adjusted Rsquare sebesar 0,412. Hal ini berarti besar kontribusi antara kebijakan publik (X1), partisipasi masyarakat (X2) dan tingkat pendidikan (X3) terhadap Kesejahteraan Masyarakat Kabupaten Padang Pariaman (Y) adalah 0,412 atau $41,1 \%$ Koefisien determinasi (r2) berguna untuk menunjukkan seberapa besar kontribusi variabel bebas terhadap variabel terikat. Hal ini dapat diartikan bahwa besar konstribusi variabel kebijakan publik (X1), partisipasi masyarakat (X2) dan tingkat pendidikan (X3) terhadap Kesejahteraan Masyarakat Kabupaten Padang Pariaman (Y) adalah sebesar 41,2\% yang sisanya 58,8\% dipengaruhi oleh variabel lain diluar variabel yang diteliti dalam penelitian ini.

\section{E. KESIMPULAN}

Penelitian ini bertujuan untuk mengetahui pengaruh kebijakan publik, partispasi masyarakat dan tingkat pendidikan terhadap kesejahteraan masyarakat Kabupaten Padang Pariaman. Berdasarkan hasil penelitian, maka kesimpulan dari penelitian ini dapat diuraikan sebagai berikut:

1. Kebijakan publik berpengaruh secara signifikan terhadap kesejahteraan masyarakat Kabupaten Padang Pariaman. Hasil ini dapat dilihat dari uji hipotesis diperoleh nilai Thitung 6,175 dengan signifikansi 0,000. Artinya bahwa semakin baik kebijakan publik maka semakin baik pula kesejahteraan masyarakat yang dihasilkan 
2. Partisipasi masyarakat berpengaruh secara signifikan terhadap kesejateraan masyarakat Kabupaten Padang Pariaman. Hasil ini dapat dilihat dari uji hipotesis diperoleh nilai Thitung 5,872 dengan signifikansi 0,000. Artinya, semakin banyaknya partsipasi masyarakat baik dalam pelaksanaan dan pengawasan maka kesejateraan masyarakat yang dihasilkan akan semakin baik pula.

3. Tingkat pendidikan berpengaruh secara signifikan terhadap kesejahteraan masyarakat Kabupaten Padang Pariaman. Hasil ini dapat dilihat dari uji hipotesis diperoleh nilai Thitung 5,665 dengan signifikansi 0,000. Artinya, semakin tinggi pendidikan disuatu daerah atau masyarakat maka akan semakin tinggi pula kesejahteraan masyarakat didaerah tersebut.

\section{F. SARAN}

Berdasarkan kesimpulan yang diperoleh dari penelitan ini, penulis memberikan saran agar dapat dijadikan panduan atau acuan untuk penelitian selanjutnya, maka terdapat berapa saran yang dapat dipertimbangkan yaitu :

1. Dalam penelitian ini penulis hanya menggunakan populasi dan sampel yang sedikit yaitu sebanyak 99 kepala keluarga di Kecamatan Sungai Limau. Diharapkan penelitian selanjutnya dapat menggunakan populasi dan sampel yang lebih besar misalnya setiap pendudukan yang ada didaerah lainnya.

2. Didapatkan penelitian selanjutnya menambahkan periode penelitian yang lebih panjang sehingga dapat menggali variabel-variabel lain yang dapat mempengaruhi Kesejahteraan Masyarakat

3. Untuk peneliti selanjuntya semoga dapat menggali lebih dalam menganai pengaruh kebijakan publik, partisipasi masyarakat, dan tingkat pendidikan terhadap kesejahteraan masyarakat. 


\section{DAFTAR PUSTAKA}

Agustino, L. (2006). Dasar-dasar kebijakan Publik. Bandung: CV.Alfabeta.

Akib, H. (2010). IMPLEMENTASI KEBIJAKAN: Apa, Mengapa, dan Bagaimana HAEDAR AKIB. Jurnal Administrasi Publik, 1(1), 1-11.

Arikunto, S. (2006). Prosedur Penelitian: Suatu pendekatan praktek (Revisi VI). Jakarta: Rineka Cipta.

Bintarto, R. (1989). Interaksi desa-kota dan permasalahannya. Jakarta: Ghalia Indonesia.

D, S. I. A. (2009). Desentralisasi dan Partisipasi dalam Pendidikan. Yogyakarta: UNY Press.

Drs. Uyoh Sadulloh, M. P. (2011). Pengantar Filsafat Pendidikan. Bandung: Alfabeta.

Dunn, W. N. (2003). Analisis Kebijaksanaan Publik (Cet.10). Yogyakarta: Hanindita Graha Widya.

Ihsan, H. F. (2010). Dasar-dasar Kependidikan: Komponen MKDK (1st ed.). Jakarta: Rineka Cipta.

Indonesia. (2009). Undang-undang Republik Indonesia Nomor 11 Tahun 2009 tentang Kesejahteraan Sosial. Suluh media.

Nasikun. (1996). Urbanisasi dan Kemiskinan di Dunia Ketiga. Yogyakarta: PT. Tiara Wacana.

Nugroho D., R. (2008). Public policy. Jakarta: Elex Media Komputindo.

Nursiah Chalid, \& Yusbar Yusuf. (2014). Pengaruh Tingkat Kemiskinan dan Tingkat Pengangguran, Upah Minimun Kabupaten/Kota Dan Laju Pertumbuhan Ekonomi Terhadap Indeks Pembangunan Manusia di Provinsi Riau. Jurnal Ekonomi, 22(2), 1-12.

Oakley, P. (1991). Projects with People: The Practice of Participation in Rural Development. International Labour Office.

Sensus penduduk 2000: statistik potensi desa Indonesia 2000 / Badan Pusat Statistik. (2000). Jakarta: Badan Pusat Statistik.

Subarsono. (2009). Analisis Kebijakan Publik Konsep. Teori Dan Aplikasi. Yogyakarta: Pustaka Pelajar.

Sugiyono. (2014). Metode Penelitian Kuantitatif Kualitatif dan $R \&$ D. Bandung: Alfabeta.

Tangkilisan, H. N. S. (2003). Implementasi kebijakan publik (cet. 1). Yogyakarta: Lukman.

Todaro, M. P. (2006). Economic development (9th ed.). NY: Addison Wesley, 2006.

Wahab, S. A. (2005). Analisis kebijaksanaan: Dari formulasi ke implementasi kebijaksanaan negara (Ed.2, cet.). Jakarta ; Bumi Aksara.

Winarno, B. (2012). Kebijakan Publik Teori, Proses, dan Studi Kasus. Yogyakarta: Caps. 